of a conceptualization of liberalization that is framed and regulated by the WTO, and which impacts the way countries craft national policies and regulatory frameworks, Jamaica is striving to understand what this means for its 2.7 million population.

With increasing evidence that national considerations of more powerful developed countries shape and often take precedence over international arrangements in conflict with their national interests and global obligations, smaller developing countries like Jamaica appear disadvantaged, because they lack the knowledge capacity to participate equitably on the international stage. To cope with this dynamic, Jamaica must accelerate the process of providing greater access to higher education. Within this context, the sector is evolving as the underpinning of the socioeconomic development of the nation but needs to integrate more closely with other crucial sectors of society.

\section{Policy Strategy}

Jamaican policymakers acknowledge the need to expand participation in higher education if the country is to narrow the knowledge gap with its major trading partners in terms of economic development. Particular challenges arise because of the

\section{Jamaica must accelerate the process of providing greater access to higher education.}

high levels of violent crime that exist (averaging I,IO० murders per year over the last Io years), and the high rate of migration among its graduates (with some estimates as high as 80 percent). Thus, making progress will not be easy, but Jamaica has to find the wherewithal to craft a coherent and visionary higher education policy that takes these contextual factors into account. To develop the human capital necessary to sustain growth and strengthen the country's global competitiveness requires policies that result from a strategy that articulates the vision, purpose, and objectives of the sector. In a real sense, therefore, higher education has the potential to underpin the country's revival, based on a profound understanding of the dynamics that prevail.

Jamaica is not the only country that needs to maneuver itself out of a difficult socioeconomic situation where higher education becomes the lever to facilitate recovery and even prosperity. However, the country also finds itself having to cope with WTO regulations, which impose obligations regarding liberalization, market access, and transparency.

At this juncture, Jamaica clearly needs consensus around its higher education policy, as only then can the policy environment honor the participation of all stakeholders, meet national objectives, and comply with WTO obligations. This policy framework must specifically address the concerns related to the GATS, clarify the role of foreign providers, ensure greater articulation in the system, strengthen the certification and accreditation mechanisms, and be more tightly linked with other key policy areas.

\section{Expansion and Quality in Bangladesh}

\section{Yuto Kitamura}

Yuto Kitamura is associate professor of international development at Nagoya University, Japan, and a visiting professor at the Japan Study Center at the University of Dhaka, Bangladesh (2005-2006). Address: Nagoya University, Furo-cho, Chikusa-ku, Nagoya 464-8601, Japan. Email: yuto@gsid.nagoya-u.ac.jp.

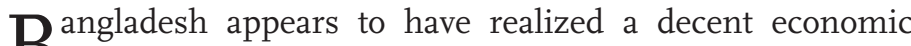
B development since the late I990s. The United Nations Development Program's Human Development Report recently ranked this nation in the middle levels of development. Reflecting the advances in economic and social development, higher education in Bangladesh has shown a significant expansion in recent years, particularly in the private sector.

\section{UniVersities IN THE SyStem}

Bangladesh has two main, separate types of higher education institutions: the highly competitive universities and a large number of degree colleges affiliated with universities. This article examines only those educational institutions categorized as universities by the University Grants Commission (UGC) - this discussion does not address the affiliated colleges or other important streams in the tertiary level of the Bangladesh education system (i.e., madrasah education).

In Bangladesh, at present, there are 75 universities $(2 \mathrm{I}$ in the public sector and 54 in the private sector), which grant diplomas in specific fields as well as bachelor's and higher degrees. For most individuals in this developing nation, access to a university education has been limited. The Bangladesh: Education Sector Review (2000), published by the World Bank, pointed out that less than io percent of the students who obtained the Higher Secondary Certificate were admitted to universities. The poor inevitably have been excluded from the education system prior to reaching the tertiary level.

\section{Rapid Expansion of the Private Sector}

The expansion of Bangladeshi higher education in recent years has largely been due to the rapid growth of the private sector. With the Private University Act in 1992, the government approved the establishment of North South University, the first private university in Bangladesh. During the I990s, around 20 government-recognized private universities were established, 
with the number increasing to 54 by the end of 2005 . The number of students attending private universities has also increased rapidly from 6,200 at 16 universities in 1997 to 44,600 at 52 universities in 2003. In comparison, the numbers for public universities increased from 74,000 students at II universities in 1997 to I04,700 at 2I universities in 2003. Although the number of students enrolled in public universities remains higher, the pace of increase for enrollment in private universities seems to have accelerated.

Some critics, however, question the quality of education offered at many private universities. Except for several private universities, many have offered programs in very limited fields; for example, business administration, computer science, information technology, and the English language. Such fields are considered "practical" and attract a large number of applicants in higher education, as increasing foreign investments in Bangladesh assist in expanding an economic market that requires a labor force trained in these fields.

Many private universities are actually established within one structure or, in some cases, only on several floors of a building. Such a constrained physical learning space affects

\section{Less than 10 percent of the students who obtained the Higher Secondary Certificate were admitted to universities. The poor inevitably have been exclud- ed from the education system prior to reaching the tertiary level.}

the quality of teaching and learning at these private universities. Many have introduced a double shifting of class schedules, while others have even divided students into four groups with morning and afternoon sessions on alternate days. It should be obvious that students cannot enjoy enough time and space for their learning in such environments.

\section{Low Quality of Teaching and Research}

Many of the faculty members in Bangladeshi universities appear unmotivated to conduct their own academic research due to such problems as a lack of research funding, absence of a staff development program, heavy teaching load, and an unclear system of recruitment and promotion. At a majority of the universities, many faculty members do not hold doctorates, and those who have finished their master's program are generally hired as new teaching staff. Although the UGC has established rules and regulations for recruitment and promotion, an obscure system remains in place for such practices, based on political connections rooted in political parties rather than on merit. Many faculty members remain involved in university politics, which is closely linked with national politics. In such an environment, faculty members tend to lose interest and motivation in producing research.

Moreover, a lack of academic research by faculty members has resulted in a low quality of teaching at universities, with limited knowledge and experience, particularly in sciencebased disciplines. At both public and private universities, most classes are conducted in a conventional lecture style in which students are expected to memorize knowledge delivered directly from the lecturers. Open discussion in a seminar style is rarely practiced.

\section{Influences in the Public Sector}

Furthermore, insufficient financial conditions for faculty members have resulted in a low quality of teaching at the public universities. The monthly salary of faculty members at a public university is considerably less than the salary of their counterparts in the private schools. It remains difficult, however, to increase compensation at the public universities because they already spend about three-fourths of their budget on staff salaries.

As a result of these limited financial benefits, many faculty members at public universities take on part-time positions at a private university, which offers better remuneration at most levels. Motivated by these economic benefits, such teachers often devote a larger amount of their time in teaching at the private university than their regular posts at public institutions. When possible, some instructors quit their posts at public universities and take up new posts at private schools. This tendency also lowers the quality of education at public universities.

\section{CONCLUSION}

Some scholars and practitioners observe that the expansion of the private sector in Bangladesh provides healthy competition for the public sector. This expansion may satisfy the social demand for improved higher education among the emerging middle class while relieving the public sector from some financial constraints in educating thousands of students. However, the main interest of many private universities is to make a profit, which in turn narrows the scope of the educational programs and lowers the quality of teaching and learning. This brief article suggests that the current situation of higher education in Bangladesh appears to form a vicious cycle in which both the public and private universities unintentionally lower the quality of education due to competition.

In order to improve the quality of education, both the public and private universities need to allocate limited financial and human resources in a more effective manner, set up a transparent system of recruitment and promotion, introduce dynamic and interactive teaching and learning styles, and reduce political activities inside the universities. 